\title{
Diplomacy for development or doom? Epistemological reflections on Uganda's recent foreign policy achievements and blunders
}

\author{
La diplomacia al servicio del desarrollo. \\ Reflexiones epistemológicas sobre los recientes logros \\ y tropiezos en materia de política en Uganda
}

\author{
Samuel H. Baligidde*
}

Abstract

This article is guided by a triangulation of neo-realist and neo-liberalist post-modernist approaches to the analysis of foreign policy coupled with Rosenau's pre-theory and Allison's models of foreign policy decisionmaking using the decision units approach, among others. It seeks to stimulate reflection on the epistemological underpinnings of the new paradigm shifts in Uganda's foreign policy in recent times. Theories will assist in epistemologically conceptualizing issues and events, creating and setting standards and benchmarking conditions for meeting the new universalistic foreign policy paradigm or in answering academic or/

Director de la East African School of Diplomacy, Governance and International Studies. sbaligidde@umu.ac.ug 
and practical questions. It is contended that there has been a significant paradigm shift towards internationalism in the country's foreign policy to ward off increasing political dissent and emerging socio-economic challenges in the domestic arena.

KeYwords: Uganda, foreign policy, internationalism, political dissent, military engagement.

\section{Resumen}

El presente artículo se basa en una triangulación de los criterios neorrealista y neoliberal posmodernos para analizar la política exterior, junto con la pre-teoría de Rosenau y los modelos de toma de decisiones de Allison en materia de política exterior que utilizan el método de unidades de decisión, entre otros. Procura estimular la reflexión sobre las bases epistemológicas de los recientes cambios de paradigma de la política exterior de Uganda. Las teorías ayudan a conceptualizar temas y sucesos, creando estándares y estableciendo puntos de referencia para satisfacer el nuevo paradigma universalista de política exterior o responder a interrogantes académicas o prácticas. Se sostiene que en la política exterior del país se ha producido un cambio de paradigma hacia el internacionalismo que apunta a detener el disenso político y al surgimiento de retos socioeconómicos en el plano interno.

Palabras Clave: Uganda, política exterior, internacionalismo, disenso político, participación militar.

Recibido el 8 de agosto de 2011; aceptado el 10 de octubre de 2011. 
Samuel H. Baligidde • Diplomacy for development or doom?

\section{INTRODUCTION}

Theories are important not only in studying and analyzing foreign policy but also in any intellectual endeavour. They provide an epistemological foundation to answering such questions such as these: Is Uganda's steadfastness in participating in international peace operations motivated by a genuine concern with peace, human rights issues, war against international terrorism, or does it have something to do with aspirations of becoming a regional military superpower and the survival of the regime? Was Uganda's support of the SPLA in its fight with the North and military engagements and skirmishes in DRC that were perceived as being belligerent during the 1990s an attempt to create a cordon sanitaire around her borders? Wasn't Uganda treading on treacherous ground when it sent its troops to Somalia and before that engaged in military adventures with almost all its neighbours thereby violating the international relations principle that contra-indicates creating enemies on more than one frontier at the same time? Whenever diplomats and policy analysts are faced with such questions they scan the environment for causal factors or drivers before they resort to theory. The academic and practical underpinnings of normative theory significantly support a case for a revisitation of the epistemological explanation for Uganda's current foreign policy.

\section{EPistemologicAl} REFLECTIONS ON FOREIGN POLICY ANALYSIS

An epistemological case can be made for why a focus on Uganda's foreign policy is gaining ground within international relations, and why it should do so. Looking for the rationale for Uganda's policy towards the United States as done by Okoth (1995:107110) has far reaching epistemological implications in understanding Uganda's foreign policy paradigm shifts on the one hand, and why the UK and USA should turn to Yoweri Museveni to reign in Libyan strongman Gaddafi or use him to do the impossible on their behalf in Somalia. When a scholar endeavors to appreciate and understand how a small, developing country like Uganda can manoeuvre among the superpowers to extract a living or to enhance its leader's political survival they are clearly within the realm of epistemology: the study of the nature and grounds of knowledge especially with reference to its limits and validity.

For example, with millions of dollars worth of Libyan investments in Uganda coupled with the sentimental feelings of a government that originally came to power in 1986 with the help of Libyan assistance in the form of arms air-dropped in the bushes of the Luwero Triangle at the peak of the bush war, the NATO allied attack on Qaddhafi's troops presented a dilemma to President Museveni who resorted to making contradictory statements 
about his government's position on what he preferred to call an insurrection supported by western powers to overthrow the Leader of the 1969 September Revolution. Could this be a symptom of a phobia about the possible consequences of the contagion of the example? Libya burst into flames as the civil strife in the Ivory Coast also raged on. Over 3,000 innocent civilians lost lives in Ivory Coast as they awaited the great "African solution". The African Union, whose solution Museveni supports, argues that this is an "African problem» which requires an "African solution»! As expected, it never came because there is none. The intransigence of Laurent Gbagbo was buttressed by the irresponsible stance of the AU. Gaddafi has been a beneficiary of this selfishness. Each time the AU publicly expresses support for Gaddafi, he murders more of the Libyan citizens, whom he calls «his people» - a detestable phrase that makes many African leaders believe they own the people they lead and so can do with or for them as they wish. There is no such a thing as an «African problem».

When this author served as a diplomat in Libya in the early 90s, Libya had an excellent road network and other infrastructure such as housing estates and supermarkets. Schools and hospitals were by African standards excellent. There were tar-macadam roads, primary and secondary schools, Mosques and Health Centres equipped to handle general surgery, in every administrative division. An average Libyan family owned two cars. If the Libyans were relatively well off; why would they now want Qaddhafi out? A tyrant cannot be genuinely benevolent; overthrowing a king and establishing a family dynasty is regressive, not revolutionary. But there is a curiously intriguing side to Colonel Qaddhafi: he is neither an intellectual nor a revolutionary.

To some people, Gaddafi may have been a good man in the past, supported good and progressive causes like the ANC, President Museveni's National Resistance Army struggle and many others but he made many mistakes which even President Museveni himself has at one point acknowledged. After South African money, Libyan money is the next most visible in investments in Uganda. But the people of Uganda and Libya remain oppressed and deprived. Whether Gaddafi outlives the NATO air strikes or not, he is the wrong man for Libya and Africa should facilitate his exit instead of asking NATO to stop the bombing. Africa's Heads of State and governments meet in Addis Ababa, Ethiopia, annually and whenever occasion demands, to discuss issues affecting the continent but after each meeting nothing happens. There is virtually nothing to show for all the millions of dollars of taxpayers' money that go into such meetings some of which Gadhafi has been providing.

Juxtaposed against its explanatory logic one finds realism in foreign policy broadly conceived, and for the sake of simplicity and linguistic consistency scholars refer to this Machiavellian 
tradition as Realpolitik for which both President Museveni and Milton Obote seem to be and have been consistent disciples and later gurus respectively. Although not opposed to allowing for the play of domestic factors in the pursuit of foreign policy, the major explanatory weight is given to material systemic-level factors in one form or another. However, although this characterization in terms of the classical divide between domestic and international politics has a long historical pedigree, it does have at least one major drawback as a standard for classifying Uganda's and contemporary foreign policy analysis.

It can be argued that this characterization of the field in terms of these two broad traditions continues to reflect a sub-disciplinary self-understanding of its development; it should be used when analysing the interests of the various stakeholders in the war waged to remove the former Libyan strongman Gaddhafi from power as well as revisiting the current state of affairs in Uganda's foreign policy. But, instead of a standard based specifically on the substantive nature of foreign policy, a study could proceed from two metatheoretical dimensions, one ontological the other epistemological, which are entirely neutral with regard to the substance of foreign policy itself.

President Museveni pulled off a diplomatic coup when explaining his foreign policy on nuclear proliferation during the visit of the Iranian leader Dr. Mahmoud Ahmadinejad a couple of years ago. Being a scrupulous realist, the President demonstrated astuteness in nuclear weapons diplomacy and in correlating his foreign policy to current thought in international affairs but opened a Pandora's box. Notwithstanding the right of every country to access nuclear energy for industrial development, the vision of a world free of nuclear weapons has been articulated by many other Statesmen before him because of the danger they pose to humanity. The last time Uganda was in the news was because of the 'buffoonery' and eccentricity of 'Big Daddy' and the excesses of its other sundry past dictators. Today it could be because of what the President has achieved mainly in the economic sector; steadfastness in taking advantage of global opportunities to mobilize foreign capital for investment and towing the Western line while reacting to international challenges that have thrust Uganda back onto the front pages.

Even though his foreign investment Policy is lauded by institutions like the World Bank, the European Union and the International Monetary Fund, observers and stakeholders at home and abroad criticize Museveni for favouring foreign investors over indigenous ones. For a person with former Marxist leanings who did not hide his disdain for diplomacy and diplomats when he first shot his way to power in 1986, his dramatic metamorphosis into an accomplished capitalist and international statesman makes the work of Uganda's diplomats in Western capitals 
a lot easier these days, but that of his critical biographers a bit daunting. His effectiveness in international diplomacy is demonstrated by the achievement of some of Uganda's foreign policy objectives: contributing to the building of a peaceful and prosperous world through Uganda's involvement in mutually beneficial multilateral trade, Peace-keeping operations in Liberia, Sudan and Somalia and the high profile international and regional conferences held in Uganda. His acceptability in international affairs can further be measured by the high profile visits of three American Presidents, Queen Elizabeth II and many others. Needless to say, the character and international acceptability of a statesman is an attribute of power just like military might, geographical position and natural resource endowment.

Does this demonstrate the NRM's Government's legitimacy and its policies in the eyes of the international community? The answer would be in the affirmative except for one disturbing setback; international leadership requires a blend of acumen for strategy, diplomatic persuasion and nimbleness which President Museveni seems to have acquired in abundance and utilized largely for his own benefit before the Obama Administration, Her Britannic Majesty's Government probably at the prompting of the Court of St James and the European Union, decided to take a closer look at his performance in democratic governance and human rights. A decade ago General Museveni and Flight-Lieutenant Jerry Rawlings were hailed by the Western democracies as 'Beacons of democracy' in Africa prompting the exhilarated former guerrilla leader to aspire to turning Uganda into, as he put it, an 'economic tiger' in the Great Lakes Region.

But for a country that is not a superpower, credibility and legitimacy in international affairs is based on respect more than the fear tigers represent. Suffice to mention that Uganda has sustained decent economic growth rates and enjoyed relative political stability which has impressed the international community. As renowned Oxford University Economics Professor Paul Collier has observed, few landlocked countries with the political history Uganda experienced have made it to middle income status. For a country that experienced one of the worst trade risk ratings in Africa during the terrifying times of the 70s and 80's, Uganda's transformation of the size and composition of its international trade is truly impressive but the economy is now in the doldrums.

The relationship between domestic and international politics in foreign policy generates considerable interest to scholars. The President's 'excellent' performance in international affairs therefore is some food for thought; why, for example, has the success story in international affairs not been significantly replicated in domestic politics in recent times, some question. The relationship between domestic and international politics in explaining a State's foreign 
policy behaviour is usually not correlated. This is because there is a marked distinction between international and domestic politics in terms of scope and content as reflected in legendary diplomat and international relations guru Henry Kissinger's assertion that 'the domestic structure is a given; foreign policy begins where domestic policy ends'.

In his article Realism and East Asia published in the Journal of East Asian Affairs XIV (1) in 2000, Denny Roy gives a hint when he alludes to the realism school's assumption that a 'onesize-fits-all' explanation of State interests rather than a 'horses for courses' approach risks obscuring the real motives for a government's behaviour in international diplomacy. The President has, as the saying in Uganda's political parlance goes, 'returned the fire' in response to Hilary Clinton's and British criticism about his recent democratic credentials. This is not surprising; the main priority of national leaders like him is the survival of the regime. For them realism in international affairs is not the same thing as in domestic politics where national security and State interests actually mean regime security.

Different scholars define Uganda's foreign policy differently; disagreements in approach often seem to be deep-seated, and not enough is known about it by many of them who are not practitioners to be able to say with epistemological certainty whether it may be differentiated from all other areas of public policy. What Cohen and Harris
(1975: 318) pointed to is an existential problem which has occupied a central place in the philosophy and history of foreign policy analysis, and which needs to be addressed as much today as has been done in the past. The first of these concerns the crucial issue of what constitutes the particular explanation of the study of foreign policy: what is it that is to be epistemologically explained? The debate is further complicated by those who contend that diplomacy is to be separated from foreign policy (Okoth, 2010:7-8).

From a practical point of view, whereas such a demarcation would have been defensible decades and even centuries ago, it is not exactly feasible today. In fact the two terms seem to have become synonyms in the current lexicon of diplomatic parlance. When people talk of American diplomacy in the Middle East or Africa, they in fact are referring to the modus operandi of both us foreign policy and the tools by which it is implemented in the area. At the beginning of the US-NATO led operation against Gadhafi's troops ввс World Service reported President Obama having stated that 'removing Gadhafi from power was part of American foreign policy' but under pressure to explain his meaning later changed the statement!

While this definitional issue may on first sight seem trivial, it in fact goes to the core of what distinguishes this field of analysis from that of diplomatic history, domestic and international politics, and hence is central to the long- 
standing issue of where and how to draw the analytical boundary between a sub-field that straddles the major disciplinary foci of political science and public policy. Secondly, this issue is also crucial to the choice of theoretically feasible tools of analysis, since the nature of a given epistemological explanation has obvious and fundamental implications for the types of explanatory variables, which in principle are appropriate and in practice insightful. Although there is a relatively consistent consensus with regard to the explanation, it is not the case with respect to Uganda's considerably more contentious political meta-theoretical issues.

\section{DeCISION UNITS, DRIVERS} AND INFLUENCE VECTORS IN UGANDA'S FOREIGN POLICY FORMULATION PROCESS

The consensus comes down to a specification of the unit of analysis that emphasizes the purposive nature of foreign policy actions, a focus on policy and the crucial role of state boundaries. The following stipulation is intended to capture these definitional aspects: foreign policies consist of those actions which, expressed in the form of explicitly stated goals, commitments and/or directives, and pursued by governmental representatives acting on behalf of their sovereign communities, are directed toward objectives, conditions and actors, both governmental and non-governmental which they want to affect and which lie beyond their territorial legitimacy.

The decisional unit approach enables us to answer such epistemological questions as who becomes involved in a decision, how, and why the decisionmakers decide the way they do (Snyder, et al, 1962:86). Decision-makers are actors at the apex of foreign policy formulation in the Government and the Ruling Party. Some are individuals, groups of individuals or a Cabal consisting of a few 1980s NRA bush war historicals, who exercise ultimate decision-making power and authority on a specific foreign policy issue. They include the President as the predominant leader at the State level, the Cabinet and the Uganda People's Defence Force (UPDF) High Command. They have the ability to commit the resources of the State and with respect to a particular problem, with the authority to make a decision that cannot be easily reversed. A matter that is critical to the State, like sending troops to Somalia, Democratic Republic of Congo or Southern Sudan, involves the highest political authorities as part of the decision unit whereas for routine matters this unit is usually at a relatively lower level.

The Permanent Secretary in the Ministry of Foreign Affairs, for example, makes decisions such as instructing delegations on how to vote in a number of international and regional conferences. Uganda's traditional actor in the foreign policy process is the Ministry of Foreign Affairs established in 1962 for the sole purpose of formulating, execut- 
ing and monitoring foreign policy but the most visible actor today is President Museveni himself, although the Army's power in politics is steadily growing (the Economist, February 14 th $^{\text {th }}$ 2009) and the Uganda Peoples Defence Forces were rated one of the strongest in Africa, a fact acknowledged by the USA, UN and AU that have assigned the UPDF with some tough tasks in the region. Kisekka-Ntale (2004) observes that the role of the Minister of Foreign Affairs has been rendered domestic, external policy being no longer the preserve of the Ministry of Foreign Affairs or the legislative branch of government but an 'invisible government' by the generals at the apex of the intelligence and security community.

However, the Minister of Foreign Affairs Sam Kuteesa happens to be a brother-in-law of the President and a member of the cabal, or inner-circle. Different States have different foreign policy institutions but all share common characteristics that have been entrenched after many years of diplomatic history, tradition, international mores and customs. Okoth (1994) also observes that Uganda's foreign policy is influenced not by the masses of the Ugandan people but by a minority. He theorizes that the turbulent domestic environment is the main factor that drives Uganda's post colonial Foreign Policies under its various previous leaders. Hagan (1987) theorizes that decision-makers's desire to retain political power means they must balance foreign policy concerns with maximi- zation of domestic support for the regime. But as Kisekka-Ntale (2004:198) observes, the citizens of Uganda have failed to appreciate Uganda's pro-active international responsibility and military adventurism that has oftentimes dragged the country into costly and risky expeditions putting the country at one time at loggerheads with all its neighbours and raising concerns from the international community.

Drivers of foreign policy are independent variables that impact on the dependent ones to cause political or diplomatic phenomena. They are movers that provide impulse or the stimulus that have motivated foreign policy decisions in a given situation in Uganda. It is hypothesized for example that President Museveni's involvement in АMISOM is driven by a sense of personal and regime insecurity resulting from increasing authoritarianism that has eroded his democratic credentials in the eyes of the western donor community whom he is appeasing by sending his own troops to missions other countries are not prepared to undertake. The appeasement policy prompts western governments especially the USA not to criticize him too openly. Besides, the mission avails him access to American arms and provides his trusted troops with the much needed experience needed to forestall an attempt by the opposition to remove him from power by force of arms. Somalia is a failed state, the war is still raging on after 20 years, hundreds of thousands have died, and 
millions of people have been displaced and become refugees. But the AU has been meeting and talking all this time. Only Uganda and Burundi have made the sacrifice to make Somalia a better place. The UPDF contingent in Somalia was recently given two US Attack Drones shortly after news about the procurement of Russian-made Shukhoi SU-30 supersonic multi-purpose longrange fighterjets leaked sparking a furore in Parliament because the Legislature did not authorize or approve the procurement that cost the Ugandan Taxpayer over 1.9 trillion shillings.

Who then shapes foreign policy in Uganda? Considering the broad historical perspective is one strategy for gauging the current state of Uganda's foreign policy. Professor Pontian Okoth's expositions on foreign policy, albeit with a strong ideological and historical tint, are quite insightful (Okoth, 2000; Okoth, 2007). Okoth, a colleague in the School of Diplomacy, states that the class that wields State power, the superstructure, shapes foreign policy, further arguing that Uganda was moulded to serve the interests of British monopoly capital interests which he maintains continue to erode Uganda's political independence because British Imperialism and that of the rest of the other Western powers, especially of the US continue to influence Ugandan affairs in a neocolonialist mode. He also alludes to the notion that Uganda's foreign policy towards the US follows a definite historical pattern.
4. Contradictions between

the Ugandan President's

DOMESTIC POLITICAL POLICIES

\section{AND FOREIGN POLICY}

\section{STATEMENTS}

The non-alignment diplomacy of the $60 \mathrm{~s}$ did not require politico-ideological or socio-structural differentiation from the two blocs nor did it require uniformity (Mazrui, 1967:35-49; Haveem and Willetts, 1974:1-35). Hence the contradictory NRM government's policy of freedom of choice between having a right to claim non-intervention in Uganda's internal affairs while overtly and covertly getting actively involved in other people's affairs when there is strong similarity or congruence with the regime's own interests. In a speech delivered at the African Union Summit in Sirte, Libya on July 1, 2009, President Museveni rejected Gaddafi's call for a United States of Africa arguing that regional political federations are more feasible than continental political unifications because they are more cohesive and that the communities in such federations are more compatible. $\mathrm{He}$ observed that the committee of seven had identified areas that could not be handled at either the national or regional levels even when regional federations are formed where feasible. He appealed to his colleagues to adopt a three tier integration formula: regional political federations where possible; a common market for the whole of Africa; and areas of joint or common action that involve cooperation in areas like trade negotiations with 
foreign countries, dealing with the desert (environment), inter-state security issues, etc (Museveni, 2009).

This was a major statement benchmarking the direction Uganda's foreign policy has taken in recent years but how does the President, Uganda's predominant leader in the foreign policy domain, reconcile his strong dislike for domestic federal institutions with his near obsession for the East African Federation for which some observers say he wants to be the first President? When foreign policy positions are inconsistent with the regime's domestic political situation political leaders may have little choice but to adjust their foreign policy to bring it in tandem with domestic realities but President Museveni seems to have chosen confrontation rather than reconciliation and compromise with the centuries old Mengo cultural establishment that has spearheaded the federal political system lobby in the country. Looked at in a different way, the role of the predominant leader with an increasingly peremptory personality within the decision-making unit, the 'cabal', is responsible for the new internationalist foreign policy paradigm but domestic politics is interfering with his pursuit of the cabal's interests and motives.

\section{A NEW INTERNATIONALIST PARADIGM IN UGANDA'S FOREIGN POLICY}

The new paradigm shifts in Uganda's foreign policy, namely, a departure from the nationalistic radicalism that characterized post-independence foreign policy rhetoric, to development diplomacy, active involvement in the processes of creating a prosperous, secure and peaceful world is a significant paradigm. Noteworthy is the fact that in the last 25 years, Uganda has played host to several high profile international conferences and meetings including the Commonwealth Heads of Government Meeting in 2007, the AU and many bilateral visits by national leaders from across the Globe. A number of important dignitaries like Pope John Paul II, Presidents Clinton and George Bush Jr, Queen Elizabeth, Prince Phillip and Heir Apparent Prince Charles, Kofi Annan, Margaret Thatcher, and Nelson Mandela, among many others from several countries began visiting Uganda after a long period during which under the leadership of Idi Amin and Obote II Uganda was considered a pariah state.

This is a significant paradigm shift from the ostracization arising from the chaos of the 1970s and 1980s when Uganda's foreign policy especially under Idi Amin bordered on the absurd. These challenges for which the Uganda Government claims to be partly providing leadership and solutions by participating in peace-building and international conflict resolution and management, particularly in the Horn of Africa, are of academic interest. Although not a hyperglobalist, President Museveni's present policy of active involvement in regional policing and peace-keeping points to a new interna- 
tionalist paradigm. The re-emergence of pan-Africanist rhetoric notwithstanding, as the widening, concretization, and growth of global interconnectedness become eminent, nationalism is gradually but surely giving way to the primacy of economic diplomacy and internationalism. Uganda's foreign policy has shifted from neutrality, passivity or non-alignment to active involvement in world affairs; taking sides, to the chagrin of some actors like the Islamic extremist groups such as Al Shabab, in disputes and conflicts to which the country was not a direct party and has already paid a terrible cost in human lives at the hands of terrorism.

\section{Postulates of the literati OVER FOREIGN POLICY ANALYSIS IN UGANDA AND BEYOND}

Earlier Uganda foreign policy researchers failed to consolidate the field in the manner once envisioned. Analysis does not follow one style or set of ideas but uses a wide variety of them and its defensiveness within a larger scholarly milieu is not engaged with the issues at the head of the curriculum of foreign policy analysis. A perusal of contents of the major international relations journals that were published between the 1990s and early 2000s gives a clear picture: very few contain titles in which the concept of 'foreign policy analysis' plays a prominent role; there are however many journals that specifically concern themselves with foreign policy per se. According to Carlsnaes (1986) interest in the development of international relations theory has grown but for the most part with little or no reference to 'foreign policy', either as an integral part of such theory or as a separate but important approach in its own right.

The FPA has been ignored in academic debates and discussions, or dismissed with reference to the distinction between the so called system level and unit level theories, the former pertaining to mainstream international politics, and the latter to the behavior of the regime in Uganda. A recent revisitation of theories of foreign policy therefore indicates that foreign policy analysis has received comparatively little attention (Rose, 1998: 145) not only internationally but also within Uganda. Alexander Wendt's declaration of lack of interest is equally symptomatic: theories of international politics are distinguished from those that have as their objective explaining the behaviour of individual states such as Uganda, or theories of foreign policy. Waltz declares, 'I am interested in international politics, not foreign policy' (Wendt, 1999: 11). Of equal significance universally, foreign policy analysts themselves seem to have become disillusioned.

As one scholar noted, 'These are testing times for foreign policy analysts. At issue is whether their area of study remains a major sub-field of international relations or whether it has become anachronistic, either subsumed or replaced by other approaches to understanding and explaining state behavior' 
in international relations (White, 1999: 37). In the same vein, Schneider (1997) has noted that despite sundry publications, the study of foreign policy as a whole is in the throes of a conceptual crisis as well as a theoretical stalemate. Nevertheless, the universal outlook reflects a disciplinary development which has put a strong structuralist-systemic paradigm in international relations during the past two to three decades and therefore also an effective valve on most approaches to analysing foreign policy. The behaviouralist tendency in American social science in the 1950s and 1960s had a decisive effect on approaches to the analysis of foreign policy. Its impact on the institutionally oriented research tradition transformed its character from being an essentially idiographic and normative initiative; analyzing particular forms of policy such as Professor Pontian Okoth's chapter on Uganda's foreign economic relations from 1962 to the beginning of the twenty-first century or prescribing better means for its formulation and implementation; to one which now aspires to generate and test hypotheses in order to develop a cumulative body of empirical generalizations about foreign policy paradigm shifts in Uganda (Okoth, 2000).

\section{THE NEO-REALIST BACKDROP IN UGANDA'S FOREIGN POLICY}

There are different variants of (neo) realism in foreign policy analysis, of which at least the following play important roles in the contemporary debate. A distinction should be made between 'aggressive' and 'defensive' types (Snyder, 1991: 11-12; Rose, 1998). To which does Uganda subscribe? During the past decade aggressive neorealism has been hyped by John Mearsheimer, who has argued that whereas the Cold War, based on bipolarity, military balance and nuclear weapons produced peace in Europe for 45 years; however its demise may produce deleterious effects on foreign policy in the long run. This pessimistic scenario follows from the application of neorealist tenets, especially of the view that insofar as the international system fosters conflict and aggression such as has been demonstrated by the recent NATO attack on Libya which, fearing the contagion of the example, Ugandan President $\mathrm{Mu}-$ seveni has condemned, rational states are compelled to pursue offensive strategies in their search for security (Layne, 1995: 130-76).

This is not at variance with the Machiavellian strategies the Ugandan President and his closest confidants seem to have adopted in both foreign and domestic policy in recent years. This philosophy characterized Uganda's aggressive posture towards its neighbours in the 1990s. The Uganda military have intervened on three occasions: in Rwanda, the Democratic Republican of Congo, and Sudan. Kisekka-Ntale (2004:197) observes that Uganda overtly and covertly did this to accomplish her foreign policy objectives. Defensive 
foreign policy neorealists do not share the pessimistic and essentially Hobbesian view of the international system, they argue instead that although systemic factors do have causal effects on the regime's increasingly repressive behaviour, they cannot account for all the state's domestic and foreign policy decisions.

Thomas Hobbes (1914) was the $17^{\text {th }}$ century thinker who sought to apply the new methods of science and the Greek rigour of logic to sociology. In his 1660 classical philosophical work Leviathan he describes power and promotes the notion of a commonwealth as an effective society. He notes that instrumental power has the sole purpose of acquiring more power. This includes wealth, reputation, and influential friends such as Museveni's friends in the names of three former American Presidents. Okoth (2007:128) contends that Uganda has emerged as a model for US and IMF/ World Bank policies in Africa, and that President Museveni is an articulate defender of those policies at pan-African fora. This is now history: Museveni has with impunity flouted all the rules of economic management. He has often taken angry swipes at his erstwhile western donors whenever their ambassadors in Kampala expressed concern about democratic governance and human rights issues in handling demonstrations against the sky-rocketing cost of living in the country.

The acquisition of Russian Shukhoi su-30 long range multi-purpose fighterjets at a cost of 1.9 trillion shillings is bound to trigger a vicious regional arms race which might increase rather than reduce international and regional tension. In the government-owned newspaper New Vision published on Friday July 21, 2011, Army Chief Spokesman Felix Kulayigye defended the purchase saying there is a need to procure the best and most effective equipment to maintain strategic advantage. "We must create and maintain an operational environment in order to give the military force freedom of action» he added.

The President's support of us postCold War policies in Africa coupled with a pro-Western foreign policy stance has been rewarded generously by the United States and its allies. But Museveni's displeasure at the US and NATO attack on Libya's strongman Gaddafi expressed in a missive distributed to all the major media houses in Uganda a few days after the war started may complicate US-Uganda relations which are never going to be the same, as the opposition asks 'for whom the bell tolls'. Hobbes rightly observed that the value or worth of a man is, as all other things, his price; that is to say, so much as would be given for the use of his power. He thus saw the quest for power as the quest for command over the power of others, 'If one can get another to use their power on behalf of his purpose, then he can add their power to his arsenal'. The us which has in the past been able to buy the compliance of President Museveni by refraining from criticizing him in public even when the security forces violate human rights 
with impunity may not be able to do so in future. But what Demosthenes said about diplomacy in ancient Athens, which in his days was synonymous with foreign policy, in ancient Athens probably applies to our age too:

«Ambassadors have no battle ships at their disposal, or heavy infantry, or fortresses; their weapons are words and opportunities. In important transactions opportunities are fleeting; once they are missed they cannot be recovered....Thus an ambassador who, in a constitution such as ours, acts in a dilatory manner and causes us to miss our opportunities, is not missing opportunities only, but robbing us of the control of events...»

\section{Conclusion}

Uganda is partly providing international leadership and solutions by participating in peace-building as well as regional conflict resolution and management, particularly in Liberia, Darfur, Southern Sudan and the Horn of Africa in Somalia. If there are perceived anomalies in the current diplomatic structures, methodologies and philosophies significant enough to undermine capacity for solving the contemporary problems of Uganda's foreign policy, then there is a need for skewing political culture and Foreign Service training towards development diplomacy. The esprit de corps of the Uganda professional foreign service needs a new philosophy of work in order to render the professional diplomatic service more relevant as an instrument for mooring foreign policy towards international development, responsibility and regional leadership. But as former US president Jimmy Carter once said, "This is a difficult age in which to be a diplomat or a politician, and a hell of a time to be a soldier» (See Howe, 1980).

\section{REFERENCES}

Allison, G. T., (1971), Essence of Decision: Explaining the Cuban Missile Crisis. Boston: Little, Brown.

Carlsnaes, W., (1986), Ideology and Foreign Policy: Problems of Comparative Conceptualization. Oxford: Blackwell.

Cohen, B. C. and S.A. Harris\&(1975), 'Foreign Policy', in Greenstein, F. I and N.W. Polsby (eds.), Handbook of Political Science, vol. 6: Policies and Policymaking. Reading, MA: Addison-Wesley.

Hagan, D. J., (1987), Political Opposition and Foreign Policy in Comparative Perspective.

Haveem, H. and P. Willetts (1974).,. The practice of Non-Alignment: On the Present and Future of an International Movement in Tandon, Y and D. Chandarana (eds)., Horizons of African Diplomacy., Nairobi: East African Literature Bureau.

Howe, R. W., (1980). Weapons. Great Britain: Abacus.

Hobbes, T., (1914) (reprinted 1965), Leviathan. London: Everyman's Library.

KiseKKa-NTAle, F. (2004), The military and foreign policy in Uganda, 1986-2004 in Mukwaya, A.B.K., Uganda Riding the Tiger: Security and Wars in the Great Lakes Region. Kampala., Makerere University Printer.

Kulayigye, F. (2011), Air power not a luxury but a necessity, New Vision, Friday, July 21, p. 13.

LAYNE,C. (1995), 'Kant or Cant: The Myth of the Democratic Peace', in Brown, M., S.M. Lynn-Jones, and S.E..Miller. (eds), The 
Perils of Anarchy: Contemporary Realism and International Security. Cambridge, MA: MIT Press.

Mazrui, A. A.(1967), On Heroes \& Uhuru Worship. London: Longman Group Limited.

Окотн, P. G. (2007), Uganda's Foreign Policy in the Post-Cold War Era: The Museveni Presidency in Adar, K, G and Schraeder (eds), (2007), Globalization and emerging Trends in African Foreign Policy, vol. 2, pp 125-133.

Окотн, P. G. (2000), Uganda's Foreign Economic Relations From 1962 to the Beginning of the Twenty-First Century in Okoth,. P.G (ed), Africa at the Beginning of the Twenty-First Century. Nairobi: Nairobi University Press.

Окотн, P. G., (1994), The Foreign Policy of Uganda since Independence toward Kenya \& Tanzania, in Oyugi, W. O., Politics and Administration in East Africa. Nairobi: East African Educational Publishers.

Rose, G., (1998), 'Neoclassical Realism and Theories of Foreign Policy' World Politics vol. 51. pp. 144-172.
Rosenau, J. N, (1966), Pre-theories and theories of Foreign Policy in Barry R $\mathrm{F}(\mathrm{ed})$, Approaches to Comparative and International Politics, Northwestern University Press,

Schneider,G., (1997), 'Die bürokratische Politik der Aussenpolitikanalyse: Das Erbe Allisons im Licht der gegenwärtigen Forschungspraxis' Zeitschrift für Internationale Beziehungen vol. 4 , pp. 107-123.

SNYDER, J., (1991), Myths of Empire: Domestic Politics and International Ambition. Ithaca: Cornell University Press.

SNyder, G. H. and P Diesin, (1977), Conflict among Nations: Bargaining, Decision Making, and System Structure in International Crises. Princeton: Princeton University Press.

Wendt, A, (1999), Social Theory of International Politics. Cambridge: Cambridge University Press.

White, B, (1999), 'The European Challenge to Foreign Policy Analysis' European Journal of International Relations Vol. 5 pp. 37-66. 